\title{
FUNGSI EKOWISATA SEBAGAI SARANA EDUKASI PELESTARIAN HUTAN TROPIS DI KABIL, BATAM
}

\author{
Robert Halim ${ }^{1)}$, Diah Anggraini ${ }^{2)}$ \\ 1) Program Studi S1 Arsitektur, Fakultas Teknik, Universitas Tarumanagara, \\ halimrobert7@gmail.com \\ 2) Program Studi S1 Arsitektur, Fakultas Teknik, Universitas Tarumanagara, diaha@ft.untar.ac.id
}

Masuk: 09-07-2021, revisi: 14-08-2021, diterima untuk diterbitkan: 23-10-2021

\begin{abstract}
Abstrak
Hutan adalah salah satu penghasil oksigen di Bumi dan tempat hidup berbagai jenis tanaman dan hewan. Keberadaan hutan di Bumi sangat penting karena ketidakhadirannya akan memiliki konsekuensi fatal bagi semua kehidupan. Salah satu dampak akibat berkurangnya jumlah hutan adalah pemanasan global, banjir, berkurangnya pasokan oksigen dan tanah longsor. Kata deforestasi sudah tidak lagi menjadi "tabu" dalam pengelolaan hutan di Indonesia.Luas hutan alam di Indonesia terus berkurang setiap tahunnya. Berdasarkan Global Forest Watch, terjadi penurunan hutan dii Indonesia sebesar $40 \%$ pada 2018. Agrikultur, penembangan liar dan pertambangan merupakan kegiatan komersial sebagai pendorong utama deforestasi. Salah satunya yaitu kota Batam telah mengalami pengurangan $45 \%$ jumlah daerah berhutan setiap tahunnya karena berbagai faktor, salah satunya adalah pembalakan liar di Kota Batam. Pendekatan biophilic dipilih dalam desain persoalan mengenai deforestasi untuk memberikan hubungan positif antar manusia dengan alam untuk mencapai manfaat lingkungan, moral, sosial dan ekonomi. Proyek ini diharapkan melalui kegiatan wisata hiburan dapat mengedukasi penduduk agar lebih memahami persoalan deforestasi dan meningkatkan kepedulian pada perbaikan lingkungan khususnya hutan tropis di Indonesia.
\end{abstract}

Kata kunci: Batam; ekowisata; hutan; hutan tropis; pelestarian

\begin{abstract}
Forests are one of the largest oxygen producers on Earth and are home to many types of plants and animals. The existence of forests on Earth is very important because their absence would have fatal consequences for all life. One of the impacts due to the reduced number of forests is global warming, flooding, reduced oxygen supply and landslides. The word deforestation is no longer a "taboo" in forest management in Indonesia. The area of natural forests in Indonesia continues to decrease every year. According to Global Forest Watch, Indonesia's forests decreased by $40 \%$ in 2018. Agriculture, illegal logging and mining are commercial activities as the main drivers of deforestation. One of them is that the city of Batam has experienced a 45\% reduction in the amount of forested area each year due to various factors, one of which is illegal logging in the city of Batam. The biophilic approach was chosen in the design of issues regarding deforestation to provide a positive relationship between humans and nature to achieve environmental, moral, social and economic benefits. This project is expected through entertainment tourism activities to educate residents to better understand the problem of deforestation and increase awareness of environmental improvements, especially tropical forests in Indonesia.
\end{abstract}

Keywords: Batam; ecotourism; forest; prerservation; tropical forest 


\section{PENDAHULUAN}

\section{Latar Belakang}

Kementerian Lingkungan Hidup dan Kehutanan (KLHK) menyebutkan bahwa luas hutan di Indonesia pada 2018 tercatat sekitar 125,9 hektare (ha) yaitu dengan seluas 63,7 persen dari luas daratan Indonesia yang menyebabkan terjadinya bencana seperti banjir, longsor, dan kekeringan yang dapat memicu global warming. Kim et al. (2016) menjelaskan bahwa adanya terjadi deforestasi yaitu disebabkan konflik pemilikan lahan, adanya pertumbuhan penduduk, kurangya kesempatan ekonomi, peraturan hukum yang sangat lemah serta kinerja pemerintah yang tidak efektif dalam permasalahan hutan.

Kota Batam menjadi salah satu kota industri di Indonesia yang juga memiliki kawasan hutan lindung yang tergolong luas. Berdasarkan Perda Kota Batam Nomor 2 Tahun 2004 mengenai Rencana Tata Ruang Wilayah Kota Batam yang dicantumkan Pasal 17 huruf a menjelaskan bahwa "Kawasan hutan lindung" perlu dijaga kelestarian dan keberadaannya karena sebagai pengatur tata air, pencegah banjir dan erosi, serta untuk memelihara kesuburan tanah. Berdasarkan data Badan Pusat Stastistik Kota Batam tahun 2014 memperkirakan bahwa luas hutan yang terdapat di kota Batam adalah sebesar kawasan hutan lindung seluas 12.890,8 $\mathrm{Ha}$, kawasan hutan produksi seluas 11.967,90 Ha, kawasan hutan Bakau seluas 18,366 Ha dan kawasan hutan konversi seluas 9.282,77 Ha. Kerusakan hutan lindung di kota Batam diduga sudah sangat parah. Berdasarkan data tahun 2019 meyebutkan bahwa adanya kebakaran hutan seluas 30 Ha dan mulai dari kerusakan yang dilakukan oleh masyarakat sendiri pengeksploitasian hutan oleh pihak yang tidak bertanggung jawab, hutan dengan ditambahnya maraknya pembalakan liar (illegal logging) akan mempercepat kerusakan hutan dan mempercepat penyusutnya hutan di kota Batam.

Dengan mendirikan eduwisata diharapkan dapat memberikan kesadaran dan memberikan edukasi kepada masyarakat bahwa penyebab dari deforestasi sehingga memunculkan suatu pemikiran untuk terus melindungi hutan.

\section{Rumusan Permasalahan}

a. Bagaimana ekowisata berperan dalam edukasi pelestarian hutan?

b. Bagaimana membuat sebuah tempat ekowisata dengan tujuan pelestarian hutan?

\section{Tujuan}

Tujuan penulisan jurnal yaitu untuk menghasilkan arsitektur proyek forest'arc-eduwisata hutan tropis yang dapat berperan untuk melestarikan hutan.

\section{KAJIAN LITERATUR}

\section{Ecology}

Ekologi atau Ecology dapat diartikan sebagai ilmu yang mempelajari hubungan timbal balik antara makhluk hidup dan lingkungannya. Istilah ekologi pertama kali dikenalkan oleh Haeckel yang merupakan seorang ilmuwan biologi pada tahun 1980-an. Ekologi ini merupakan gabungan dari bahasa Yunani yaitu oikos yang maksudnya rumah dan logos yang arti tersendirinya adalah ilmu. Sehingga ketika digabungkan kedua kata tersebut pun dapat ditafsirkan sebagai ilmu mengenai rumah tangga makhluk hidup (Kristanto, 2002).

\section{Ekologi dalam arsitektur}

Menurut Yeang (2006), pendekatan ekologi dalam arsitektur didefinisikan dengan Ecological design is bioclimatic design, design with the climate of the locality, and low energy design. Dengan demikian terdapat integrasi antara kondisi ekologi setempat, iklim mikro dan makro, 
kondisi tapak, program bangunan atau kawasan, konsep, dan sistem yang tanggap terhadap iklim, serta penggunaan energi yang rendah.

Menurut Dinur (2007) dalam Interweaving Architecture and Ecology A Theoretical Perspective terdapat tiga prinsip-prinsip ekologi yaitu fluktuasi, stratifikasi, dan saling ketergantungan dimana bahwa arsitek dan desainer tidak benar-benar mengerti bagaimana sistem kehidupan berfungsi, tetapi sebaliknya mencoba untuk meminjam ide-ide baru dari ilmu pengetahuan dan ekologi dan mengekspresikannya dengan arsitektur dalam cara yang singkat, dibuktikan dari penjelasan masalah sub bidang ekologi yang membahas bahwa ekologi adalah studi sistem kehidupan dan hubungan satu sama lain.

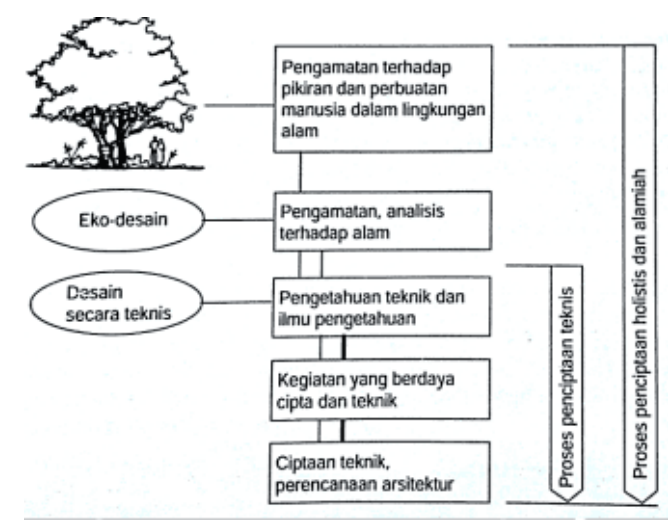

Gambar 1. Pola Pikir Desain Arsitektur Ekologis Sumber: Frick, H. (2007).

\section{Deforestasi}

Menurut Giri (2007) deforestasi merupakan sebuah proses pengonversian sebuah kawasan hutan menjadi sebuah lahan non-hutan seperti gurun atau bekas tebangan, pengunaan perkotaan, dan lahan subur. Kemudian, Food and Agriculture Organization atau yang disebut juga dengan FAO juga menjelaskan deforestasi sebagai suatu proses pengonversian kawasan hutan menjadi lahan lain dengan cara mengurangi penutupan kanopi pohon pada periode yang panjang dengan ambang batas dengan angka kurang dari $10 \%$.

Pada dasarnya deforestasi memiliki kaitannya dengan banyak faktor, salah satunya merupakan faktor sosio-demografis seperti terjadinya pertumbuhan penduduk, kegiatan eksploitasi akibat proses komersil, ekonomi politik pada struktur kelas, pertanian, dan peternakan (Giri, 2007).

\section{Eco tourism}

Menurut Bjork, Eco tourism ini adalah sebuah bentuk pariwisata yang popular dikarenakan adanya penghijauan pasar, kemudian menyebarkan pengetahuan mengenai rapuhnya lingkungan, manajer yang berinformasi, dan adanya kesadaran mengenai keterkaitan antara kebaikan ekologi dan ekonomi dengan baik.

Kemudian, perlu diketahui bahwa ecotourism ini sudah diakui memiliki manfaat untuk mencegah dampak negative terhadap lanskap yang digunakan (Sekartjakrarini, 2009).

S. Sekartjakrarini (2009) menguraikan eco tourism sebagai sebuah konsep berkembangnya suatu kegiatan pariwisata dengan proses pemanfaatan lingkungan dengan tujuan melindungi lingkungan itu tersendiri dengan cara mengajak masyarakat luas untuk kiat secara aktif mempelajari nilai nilai dari lingkungan yang dimanfaatkan sebagai objek wisata. Potensi Batam yaitu target pariwisata yang berlibur ke Batam jadi eco-tourism menjadi pilihan yang tepat dikarenakan adanya terminal ferry international, Kawasan industri dan perdagangan, dan resort. Siregar (1999) menyatakan bahwa hingga saat ini telah adanya perkembangan paradigm baru pada proses terjadinya pengelolaan konservasi. Perbedaannya adalah pada paradigm baru 
terjadinya pemberdayaan masyarakat dalam ikut mengambil peran dalam proses pengelolaan berbagai Kawasan dengan dasar tertentu seperti co-ownership, co-responsibility, dan cooperation.

a.Co-ownership merupakan prinsip dimana kawasan akan dibangun sebagai sebuah ekowisata dengan milik bersama

b.Co-responsibility merupakan prinsip dimana proses kelola eduwisata dilakukan oleh semua pihak seperti pemerintahan, stakeholders, dan masyarakat dalam ikut serta melindungi dan mengolah kawasan tersebut.

c.Cooperation merupakan prinsip dimana dalam pengelolaan kawasan tersebut terdapat berbagai peran yang harus dilakukan oleh berbagai pihak seperti para stakeholder dan masyarakat.

\section{METODE}

Metode: Biophilic design

Menurut Browning (2014), Konsep ini menawarkan kesempatan yang menarik untuk mencapai manfaat lingkungan, moral, sosial dan ekonomi sekaligus. Desain biophilik memiliki tujuan untuk menghasilkan suatu ruang yang dapat berpartisipasi dalam peningkatan kesejahteraan hidup manusia secara fisik dan mental dengan membina hubungan positif antara manusia dan alam.

a. Pola alam dalam ruang

- Visual connection with nature (pandangan lansung terhadap unsur alam)

- Non-visual connection with nature (melalui pendengaran, penciuman dan sentuhan.

- Non-rhythmic sensory stimuli (berlangsung dengan alam sebentar)

- Thermal \& airflow variability (Perubahan pada suhu melintasi kulit)

- Presence of water (melihat dan menyentuh air)

- Dynamic \& diffuce light (memanfaatkan cahaya dan bayangan)

- Connection with natural (kesadaran terhadap alam)

b. Pola analogi alam

- Biomorphic forms \& patterns (simbolis yang berpola dan bertekstur)

- Material connection with nature (Bahan dan elemen dari alam)

- Complexity \& order (Spasial serupa dengan yang dapat dijumpai dengan alam)

c. Pola sifat ruang

- 11. Refuge (tempat dimana individu terlindungi dari belakang dan atas)

- 12. Mystery (ruang yang memiliki rasa antisipasi)

- 13.Risk/peril (perlindungan yang dapat diandalkan)

Dalam perancangan proyek eduwisata melalui pendekatan biophilic akan diterapkan dalam:

a. Entrance: Visual connection with nature, Complexity \& order

b. Zoning: -

c. Massa: Dynamic \& diffuce light, Biomorphic forms \& patterns, Refuge

d. Sirkulasi: Visual connection with nature, Presence of water, Connection with natural

e. Struktur: Non-visual connection with nature, Thermal \& airflow variability

f. Utilitas: Non-visual connection with nature, Thermal \& airflow variability

g. Selubung: Visual connection with nature, Biomorphic forms \& patterns

h. Ruang dalam: Visual connection with nature, Dynamic \& diffuce light, Risk/peril

i. Ruang luar: Visual connection with nature, Non-rhythmic sensory stimuli, Presence of water 


\section{DISKUSI DAN HASIL Investigasi Kawasan}

Kecamatan Nongsa, kelurahan Kabil, bekas terminal umum

Menurut BPS, Kecamatan Nongsa merupakan salah satu kecamatan dari 12 (dua belas) kecamatan yang ada di Kota Batam. Permukaan tanah di kecamatan ini pada umumnya dapat digolongkan datar dengan beberapa variasi perbukitan rendah dengan ketinggian maksimum 60 meter di atas permukaan laut, terdapat juga sungai kecil dengan aliran air yang sangat pelan serta semak belukar yang diselingi hutan muda pada hulunya. Luas wilayah daratan kecamatan Nongsa yaitu $11,187 \mathrm{~km} 2$ dan perairan yaitu $28,811 \mathrm{~km} 2$ dengan penduduk berdasarkan hasil registrasi penduduk mencapai 69.018 jiwa. Kawasan hutan lindung yaitu hutan Muka Kuning sebesar 2.065,62 Ha.

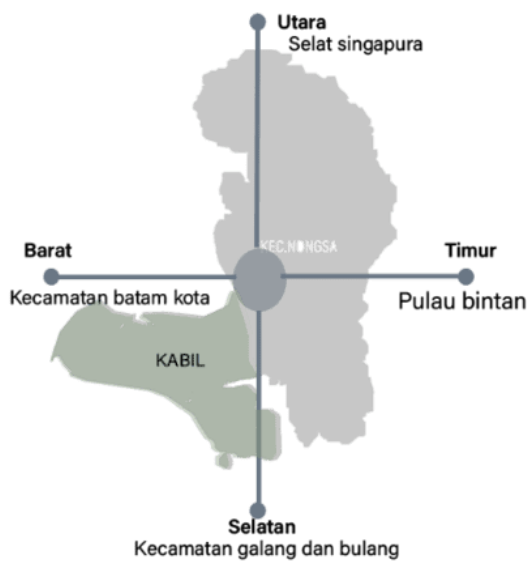

Gambar 2. Kecamatan Nongsa

Sumber: Penulis,2021

Pqarameter pemilihan tapak: 1) Kawasan yang dekat dengan hutan lindung dimana menjadi adanya aktivitas pembalakan liar. 2) Kawasan yang berada di pinggiran kota, dekat dengan industri, dan menjadi target proyek yang bermanfaat untuk hutan sekitarnya.

\section{Pemilihan Tapak}

Menurut BPS, Kabil adalah kelurahan di kecamatan Nongsa, Kota Batam, Kepulauan Riau, Indonesia. Luas wilayah kelurahan ini adalah 48,11 km, dengan jumlah penduduk tahun 2020 sebanyak 31.379 jiwa dan kepadatan $652 \mathrm{jiwa} / \mathrm{km}$.

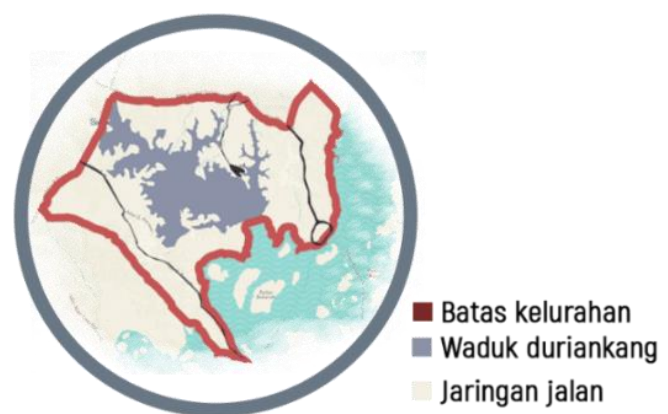

Gambar 3. Peta Batas Kelurahan Kabil Sumber: Penulis, 2021

Dari tata guna lahan merupakan terminal umum namun terminal tersebut sudah tidak terpakai dan terbengkalai sehingga merusak lingkungan sekitarnya dan sekitarnya merupakan hutan dimana terjadinya pembalakan liar. Lokasi tapaknya disekitarnya merupakan industri yang 
menjadi potensi dari visi dan misi proyek serta belakang tapak merupakan hutan Duriankang dimana menjadi kegiatan pembalakan liar sehingga tapak tersebut cocok untuk dijadikan eduwisata dengan luas $20.0000 \mathrm{~m} 2, \mathrm{KDB} 40 \%$, KLB 1, KDH 60\% dan KB 2 sehingga perlu banyaknya $\mathrm{KDH}$ dalam tapak sehingga menyatu dengan hutan sekitarnya.

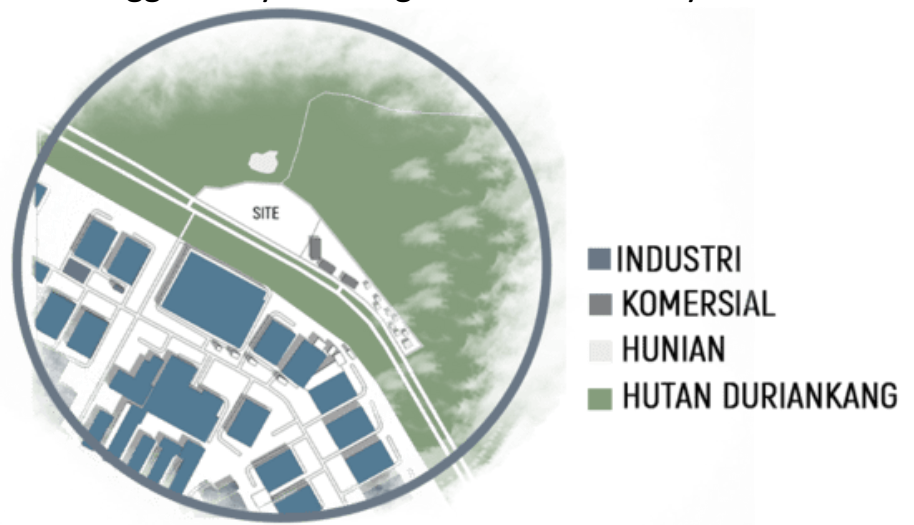

Gambar 4. Tapak Sekitarnya Sumber: Penulis,2021

\section{Analisis Tapak}

Tapak dikelilingi oleh bangunan beragam, mulai dari industri, komersial dan hunian warga sekitarnya sehingga banyak tekstur homogen sedangkan hunian dengan tekstur tidak jelas. Untuk bangunan sekitarnya juga 2-3 lantai. Pencapaian tapak melalui jalan kolektor primer tidak macet sehingga pencapaian ke tapak lancar serta tapak tersebut merupakan elemen keras sehingga perlu pencampuran antara elemen keras dan elemen lunak pada tapak tersebut.

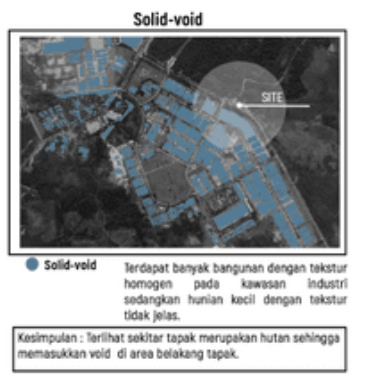

Hierarki jalan

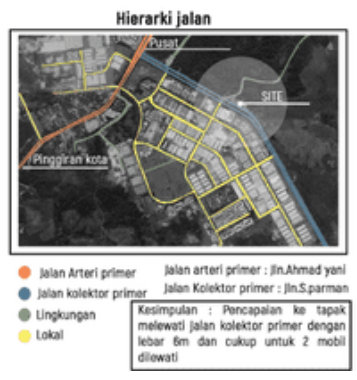

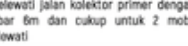

Ketinggian bangunan

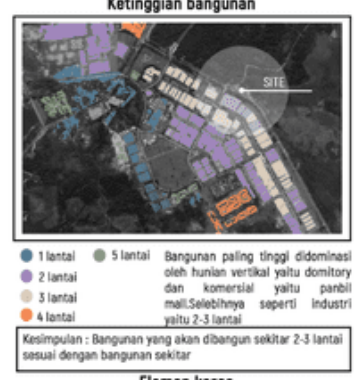

Elemen keras

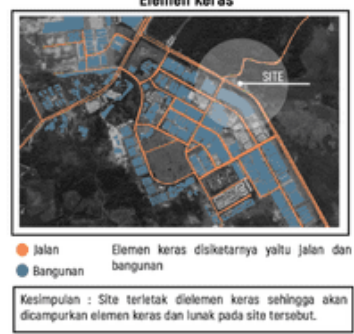

Tata fungsi lahan

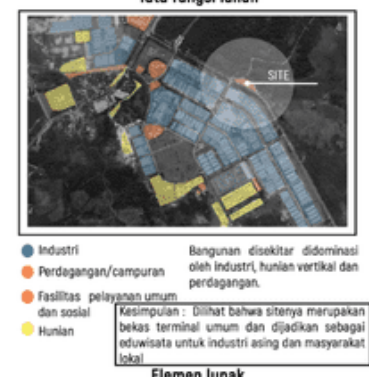

Elemen lunak

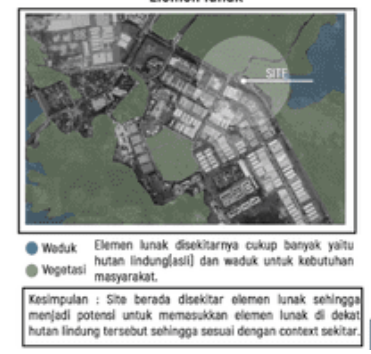

Gambar 5. Landskap Urbanism

Sumber: Penulis,2021

\section{Program Kegiatan}

Program utama yang diambil untuk menyadarkan semua kalangan mengenai deforestasi yaitu: Visitor center terdiri dari gallery, exhibition, community forestry dan market place

- Gallery: Menikmati berbagai gambar, poster, lukisan mengenai deforestasi

- Exhibition: Menikmati led screen mengenai deforestasi

- Market place: Tempat untuk menjual souvenir

Community forestry terdiri dari library, penelitian dan jagawana

- Library: Membaca buku-buku mengenai hutan dan sebagai pusat informasi hutan 
- Jagawana: Sebagai pengawas hutan dan menjaga forest park.

- Penelitian: Meneliti hutan - hutan dan hutan di forest park

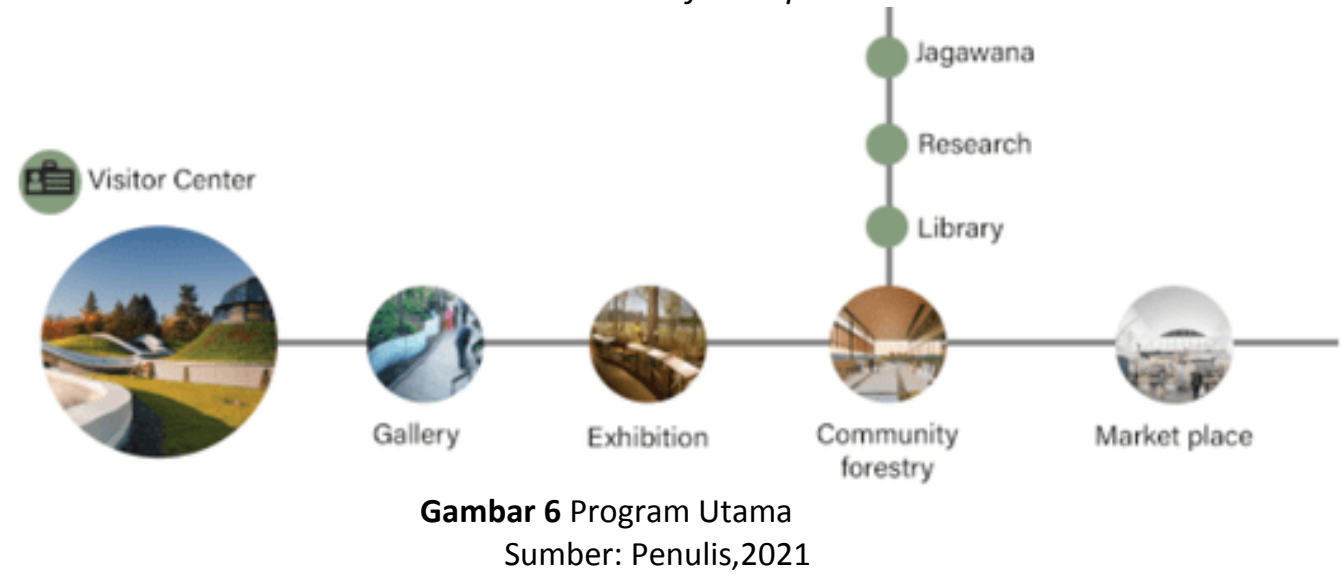

Forest park - pengunjung dapat menikmati hutan buatan mulai dari indonesia timur - indonesia tengah- indonesia barat yang terdiri dari:

- Observation tower: Pengunjung dapat menikmati view dengan elevasi yang tinggii dan menikmati keindahan hutan.

- Elevated walkway: Pengunjung dapat menikmati infografik mengenati hutan dan menikmati view ruang luar dengan elevasi tinggi.

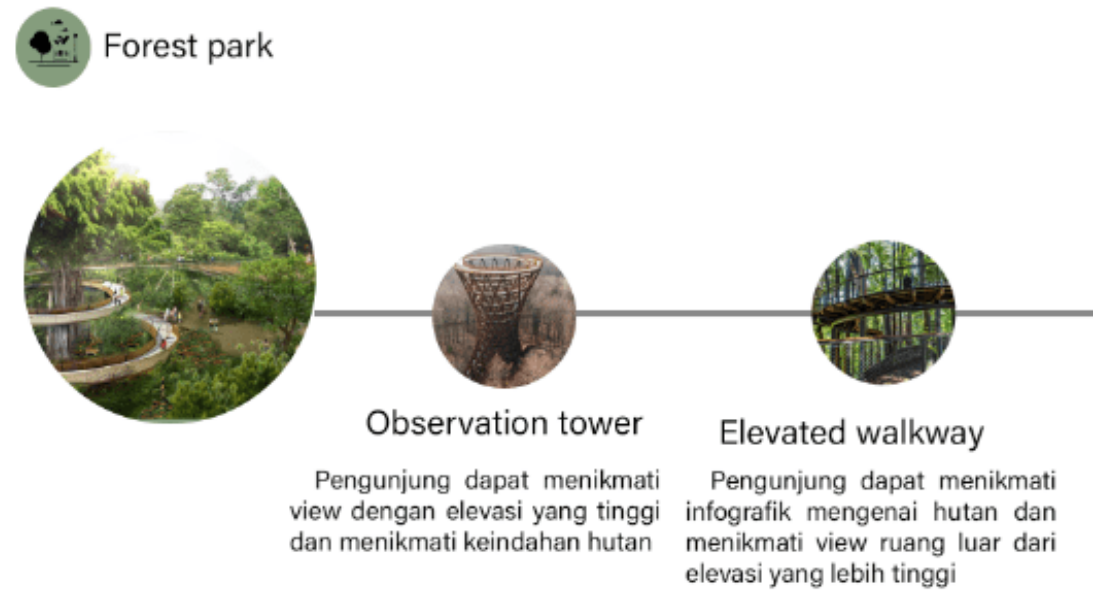

\section{Konsep gubahan massa}

Gambar 7. Program Utama

Sumber : Penulis, 2021

Proses pembentukan massa mengacu tahapan sebagai berikut :

- Context : dikelilingi oleh jalan dan hutan dengan gsb dan $\mathrm{kdb} 40 \%$.

- Level up : Massa dengan KB 2 dan dinaikkan menjadi 2 lantai sehinggai sesuai dengan sekitarnya.

- Slice \& program : Massa akan dipisah/dipootong sesuai dengan program dimana visitor centre dan community berpisah. Community berada di sisi kiri dan Visitor center diletakkan bagian kanan( dekat langsung dengan hutan sekitar).

- Fillet : Fillet bagian depan untuk memaksimalkan view dari jalan ke bangunan dan memiliki bukaan serta sirkulasi untuk parkir.

- Fillet 2 : Fillet bagian belakang untuk forest park sehingga menyatu dengan hutan sekitar dan dengan melengkung juga dapat memaksimalkan view ke hutan.

- Connecting : Memberikan koneksi antara eksibisi dan galeri sambil menikmati view forest park. 
- Void : Memberikan void pada masing-masing massa untuk mendapatkan cahaya alami langsung dan terdapat vegetasi antara bangunan dengan yang lain.

- Memberikan kolom disetiap void untuk menyanggah atap yang memberikan kaarateristik jamur.
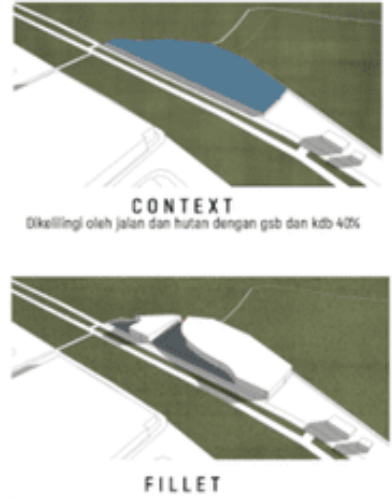

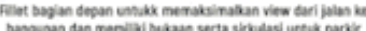

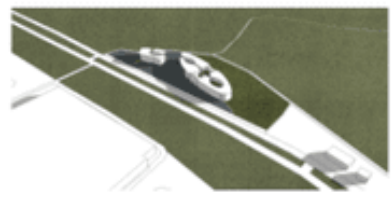

volo

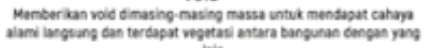
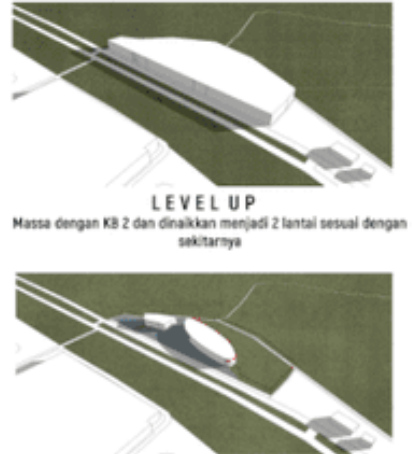

FILLET2
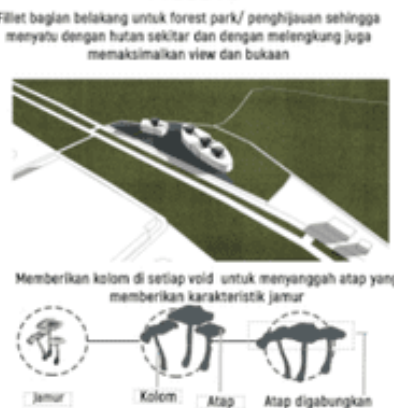

Gambar 8. Proses Gubahan Massa Sumber : Penulis,2021
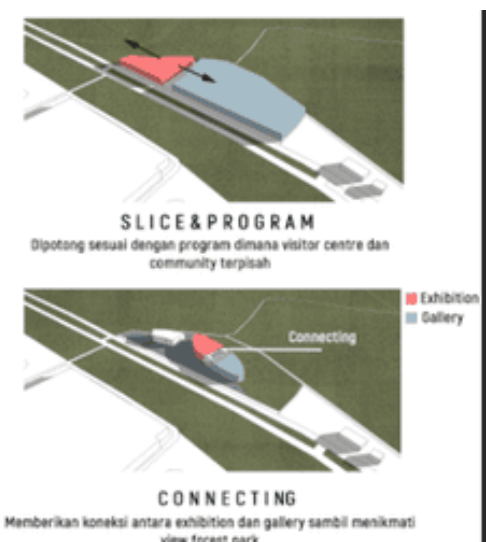
viesterest pars

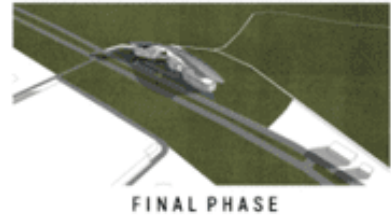

FINALPHASE

\section{Program}

Berdasarkan gambar 9, penulis dapat menghadirkan berbagai wadah untuk semua kalangan serta turis/pengunjung yang mengunjungi tapak mulai dari jln S. Parman dengan parkir didepan dan setiap massa mempunyai masing-masing drop lobby sehingga bagian privasi dan publik terpisah. Bagian samping community terdapat area service sampai ujung kanan, dengan ini maka service yang untuk menampung daun-daun dari forest park bisa terkumpulkan. Bangunan terpisah namun atap saling menyatu yang menjadi konsep dari gubahan massa sehingga jika dilihat dari atas seperti satu massa.

\begin{tabular}{cl}
\hline Pengguna & Keperluan/aktivitas \\
\hline Pengunjung/turis & $\begin{array}{l}\text { Menikmati eksibisi dan galeri serta forest park dan juga bisa menikmati } \\
\text { view hutan dari ketinggian. }\end{array}$ \\
\hline Jagawana & $\begin{array}{l}\text { Menjaga hutan, mengawasi hutan serta memaintanence hutan buatan di } \\
\text { forest park }\end{array}$ \\
\hline Pengelola & Mengatur bagian dalam bangunan serta tiket-tiket dan lai- lain \\
\hline \multicolumn{1}{c}{ Tabel 1. Pengguna dan Aktivitasnya } \\
Sumber : Penulis,2021
\end{tabular}

\section{Hasil Desain Bangunan}

- Sesuai dengan metode yang diambil yaitu biophilic design, mulai dari entrance masuk ke dalam bangunan akan berinteraksi dengan alam sebentar sehingga adanya koneksi antara alam dan manusia. 


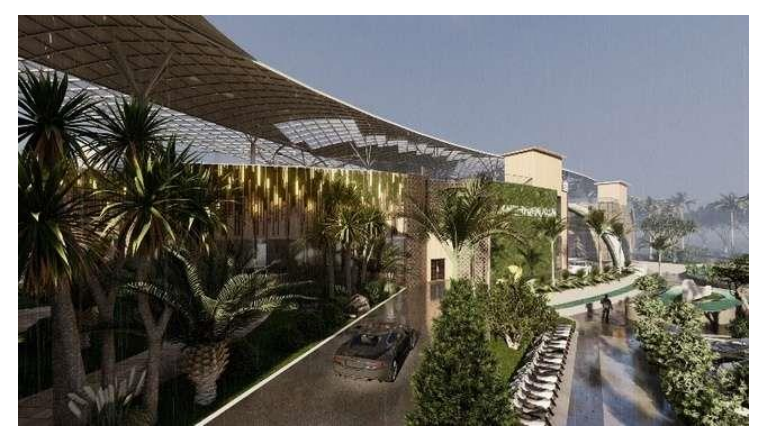

Gambar 9 Entrance

Sumber : Penulis,2021

- Setiap pengunjung juga merasakan adanya penghijauan di dalam bangunan akan selalu berinteraksi dengan alam melalui konsep gubahan massa dimana setiap bangunan memiliki void seperti pada gambar 9.

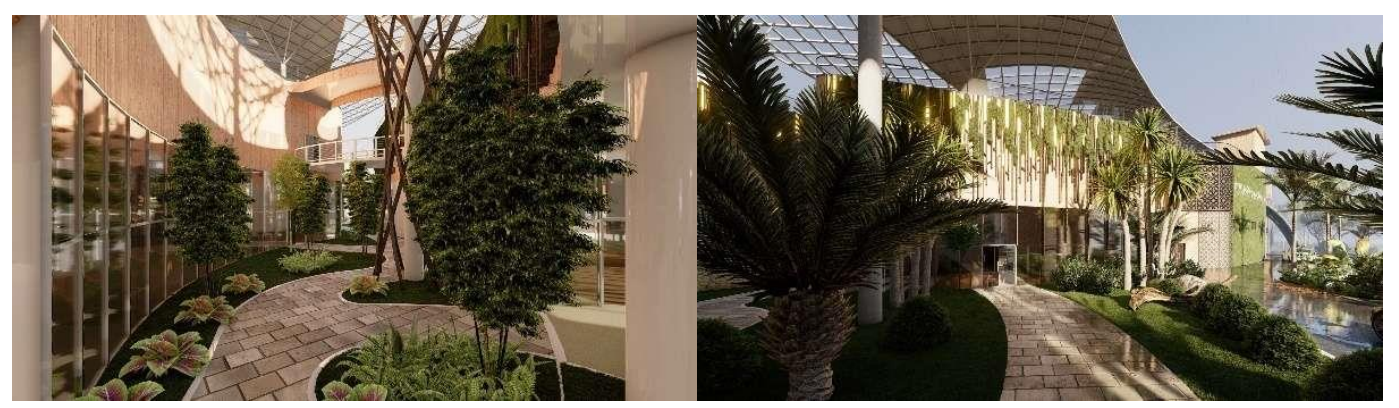

Gambar 10. Void

Sumber : Penulis, 2021

- Pada lantai 3 juga bisa melihat view dari atas untuk melihat suasana hutan dibelakang bangunan serta disediakan roof top garden sehingga juga bisa menikmati tumbuhantumbuhan yang berbeda.

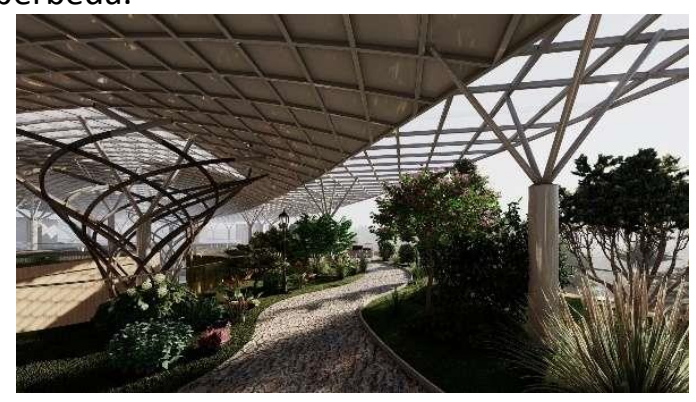

Gambar 11. Rooftop Garden

Sumber : Penulis, 2021

- Bagian forest park juga bisa merasakan berada di hutan-hutan dengan berbagai jenisjenis hutan serta adanya merasakan suara air, suara dari pohon dan batu-batu.

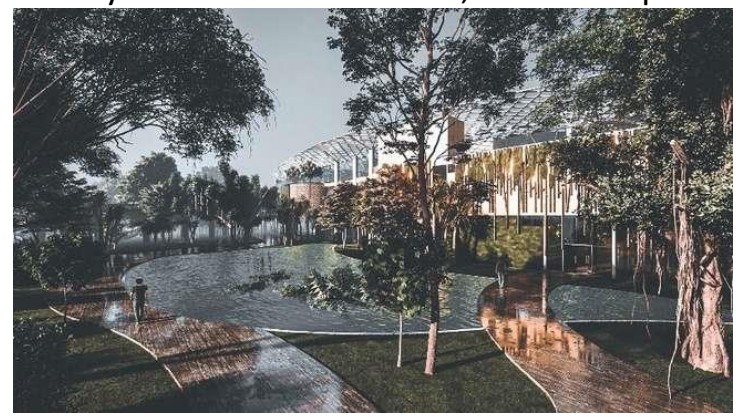

Gambar 12. Forest park

Sumber : Penulis,2021 


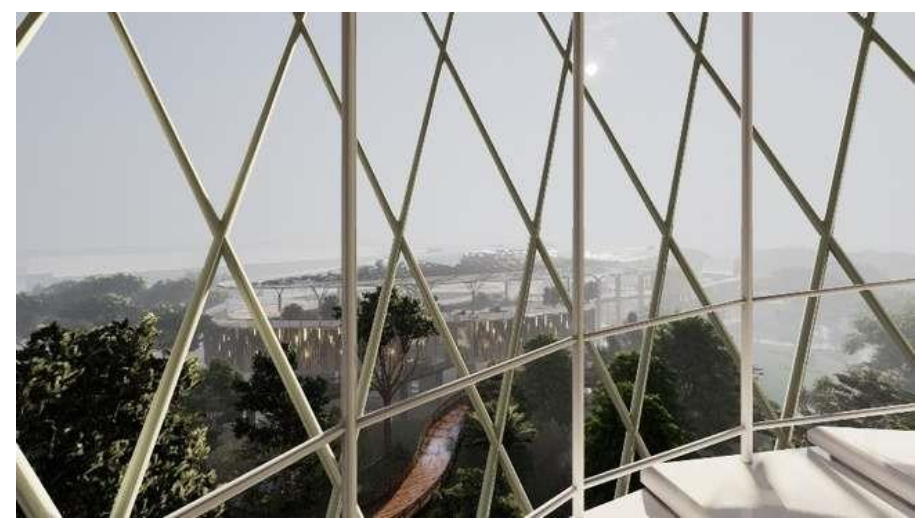

Gambar 13. View dari Obserbation Tower

Sumber : Penulis,2021

- Melalui potongan perspektif, orang cenderung lebih banyak berinteraksi dengan pohonpohon dalam bangunan. Mulai dari lantai 1 dapat berinteraksi dengan alam pada void, lantai 2 juga dapat berinteraksi dengan alam sebentar dengan melihat galeri dan eksibisi pada bangunan tersebut. Terlihat juga bahwa bangunan tersebut disesuaikan dengan pohon-pohon pada belakang bangunan.

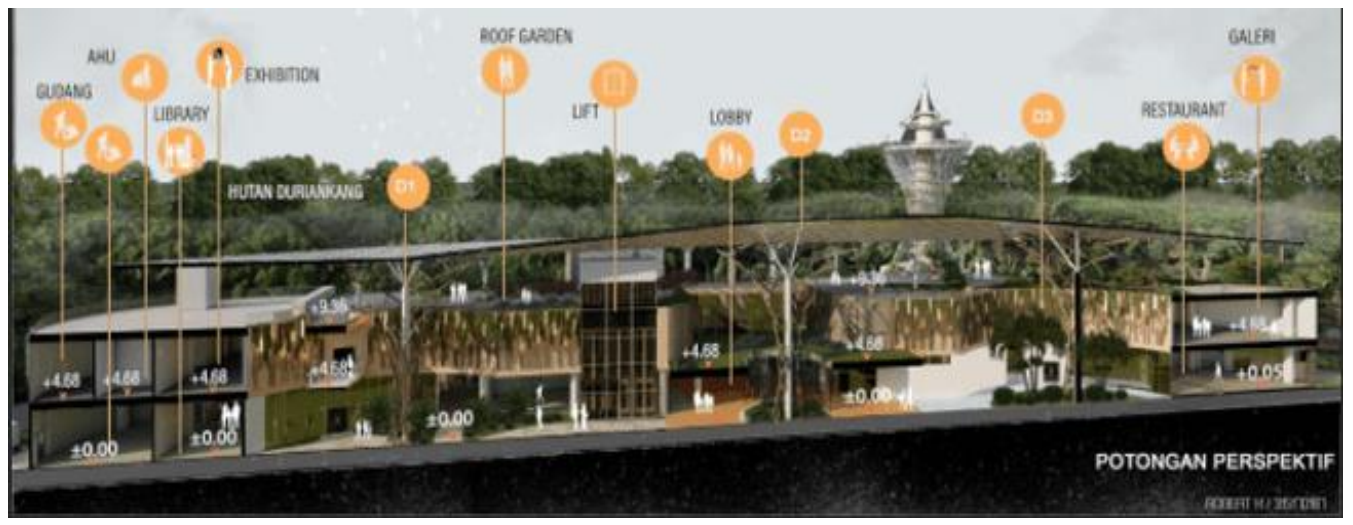

Gambar 14.Potongan Perspektif

Sumber : Penulis, 2021

- Untuk community center yang berinteraksi dengan alam hanya berada diantara bangunan visitor dan community karena tujuan adanya bangunan tersebut untuk mengelola serta tugas merawat pohon-pohon di forest park dan melakukan adanya maintenance secara rutin.

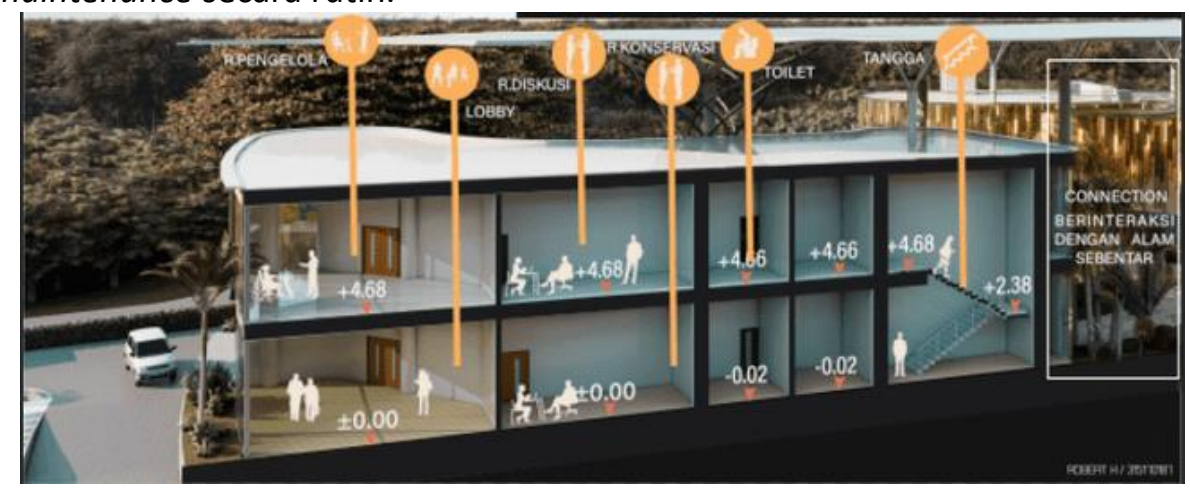

Gambar 15. Potongan Perspektif Community Center Sumber : Penulis,2021 


\section{Zoning}

Zoning untuk visitor center mulai dari lantai 1 yaitu lounge, restaurant/kafe, perpustakaan, workshop dan gudang dimana pengunjung bisa lansung ke lounge, restaurant, perpus, workshop dan gudang untuk service. Melalui restaurant juga bisa langsung ke forest park sehingga pengunjung leluasa di lantai 1 serta adanya pandangan unsur alam dikarenakan adanya void yang diisin vegetasi. Untuk lantai 2 , pengujung dapat bisa menikmati galeri dan eksibisi dan juga bisa melalui galeri langsung menuju elevated walkway dan lantai 3 untuk roof garden.

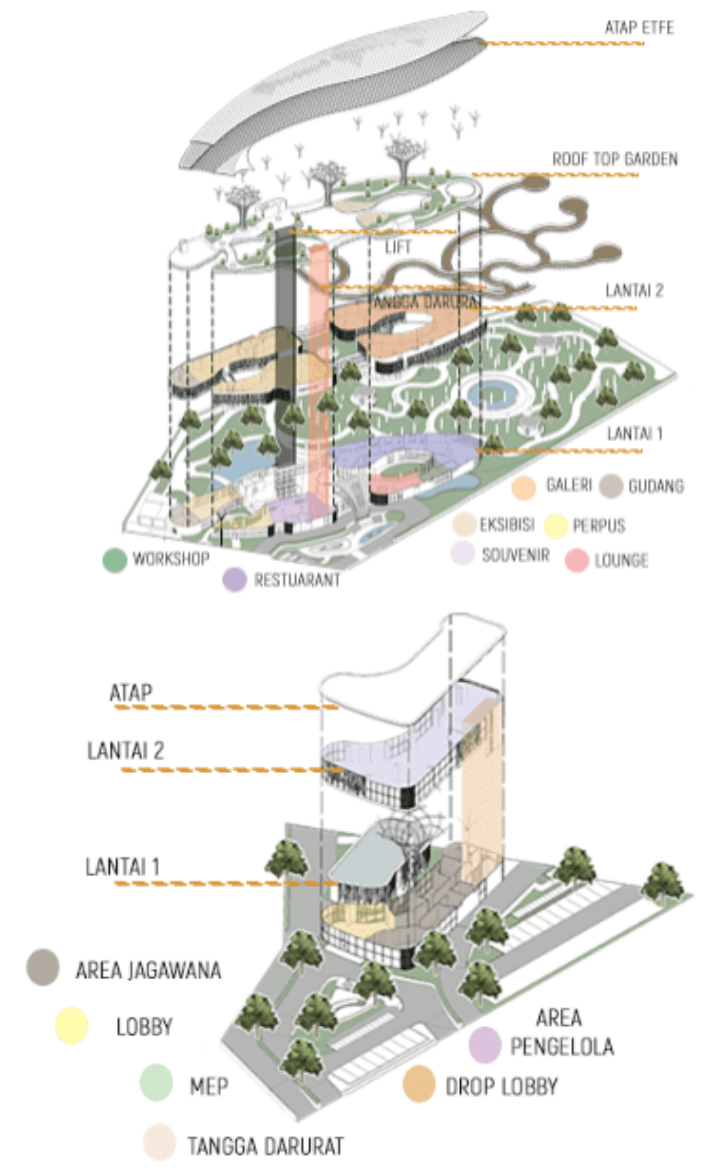

Gambar 16. Zoning Visitor Center dan Community Forestry Sumber : Penulis, 2021

Zoning untuk community di lantai 1 terdiri dari lobby, r. seminar, r. rapat, loker karyawan serta musholla untuk jagawana serta pengelola, sedangkan lantai 2 untuk pengelola untuk mengolah visitor center.

\section{Sistem struktur}

Struktur atap menggunakan ETFE yang mempunyai kelebihan yaitu: sangat ringan, efektif biaya, banyak variasi, kontrol terhadap transmisi cahaya, kontrol terhadap transmisi UV, low maintenance dan perawatan mudah. Pada gambar 10, detail 1 yaitu kolom struktur yang menjadi penyangga atap. Detail 2 merupakan detail ETFE. 

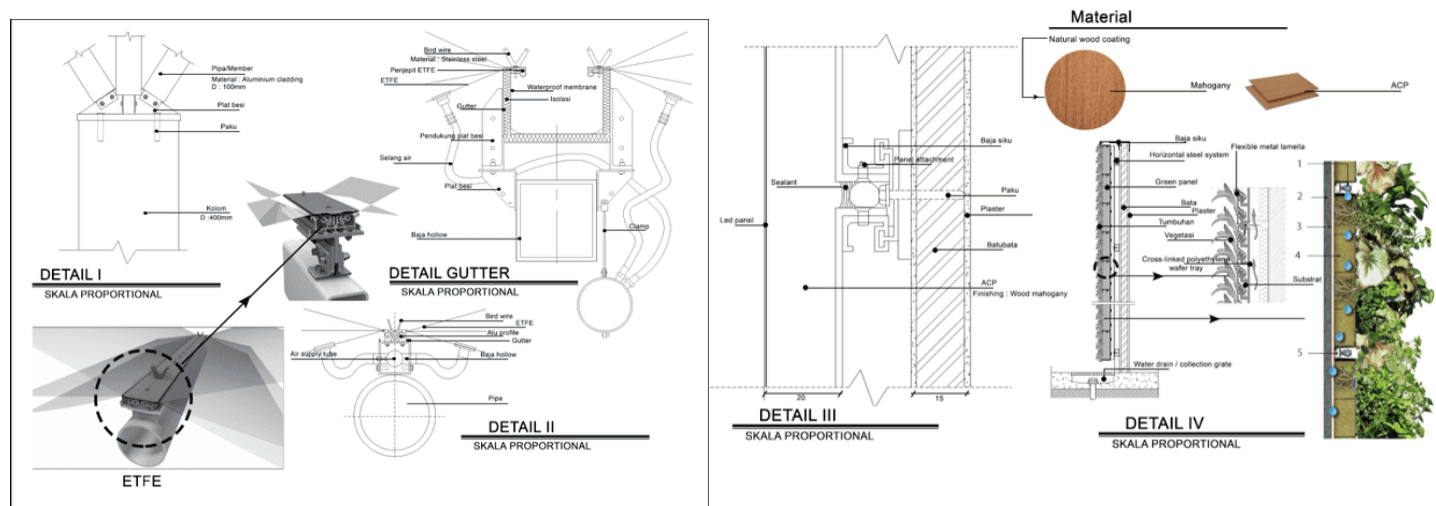

Gambar 17. Detail ETFE dan Detail fasad-Green Wall Sumber : Penulis,2021

Untuk fasad sendiri menggunakan ACP yang diberi di coating 'mahogana' sehingga tidak perlu menggunakan kayu asli sehingga bisa mencegah dari penebangan pohon dan ACP juga dapat bertahan lama. Untuk detail 4 yaitu green wall yang menggunakan sistem tanaman yang menyerupai dinding seshingga menjadikan dinding yang menarik.

\section{Visualisasi Proyek}

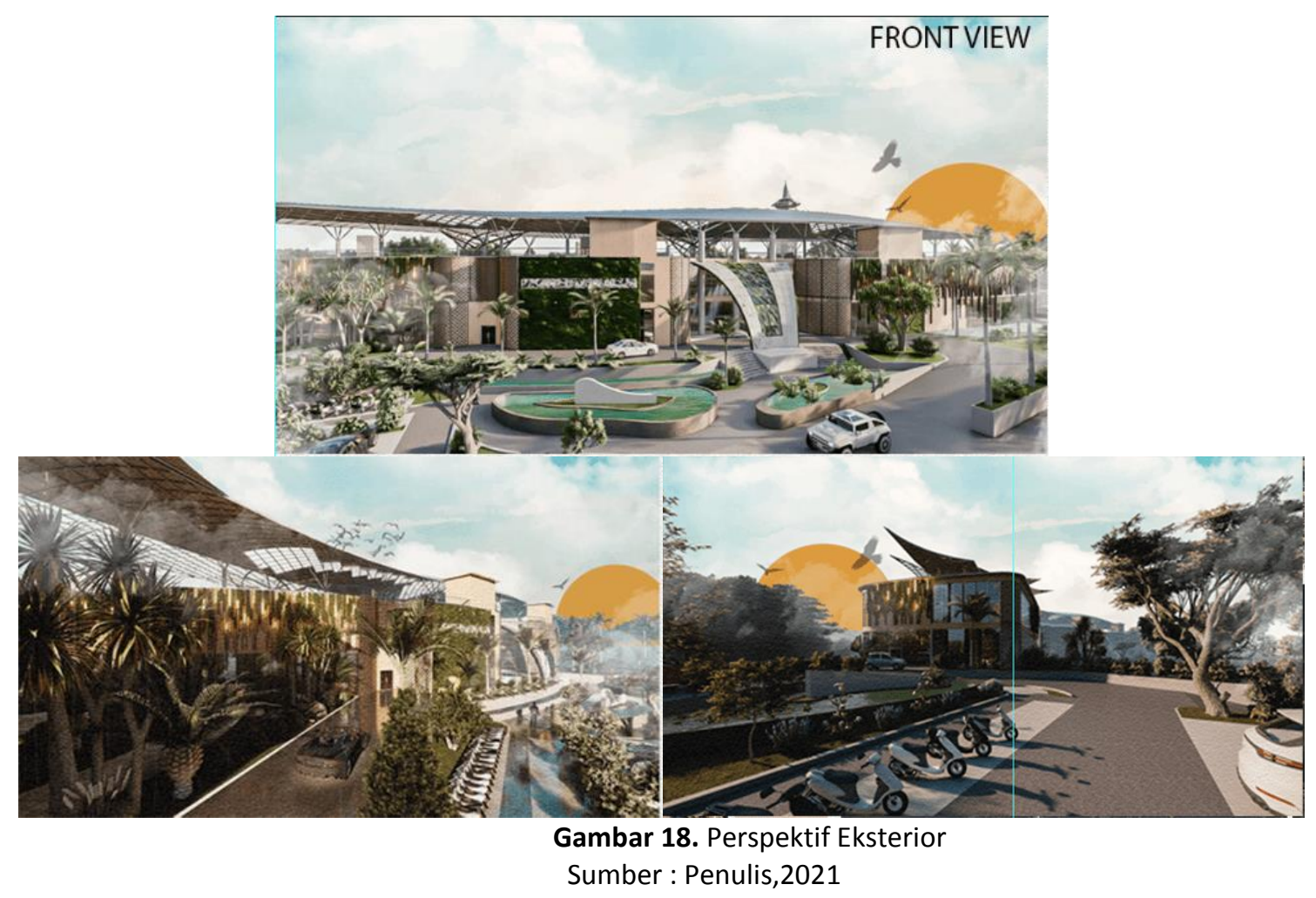



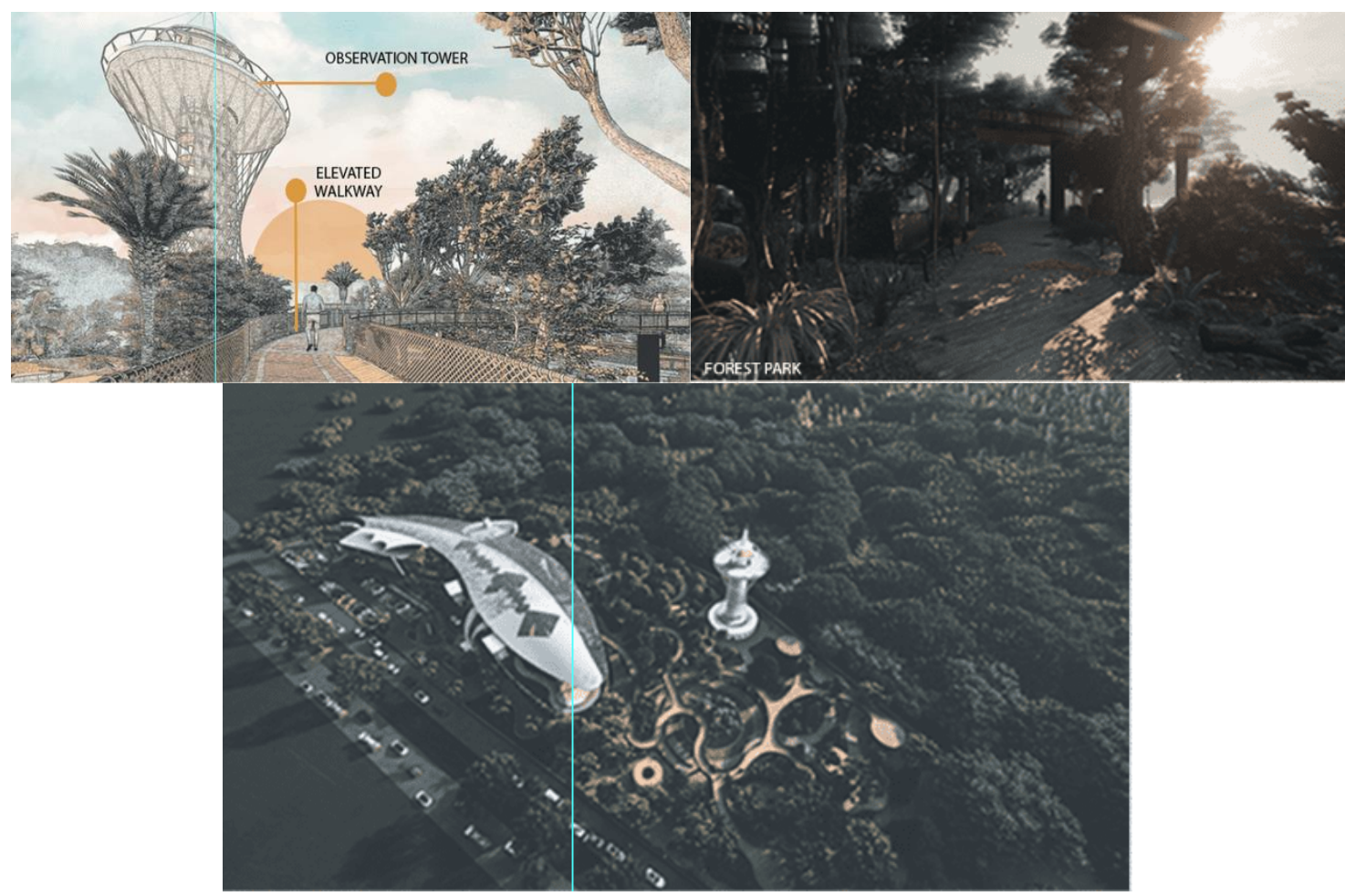

Gambar 19. Perspektif Eksterior

Sumber : Penulis, 2021

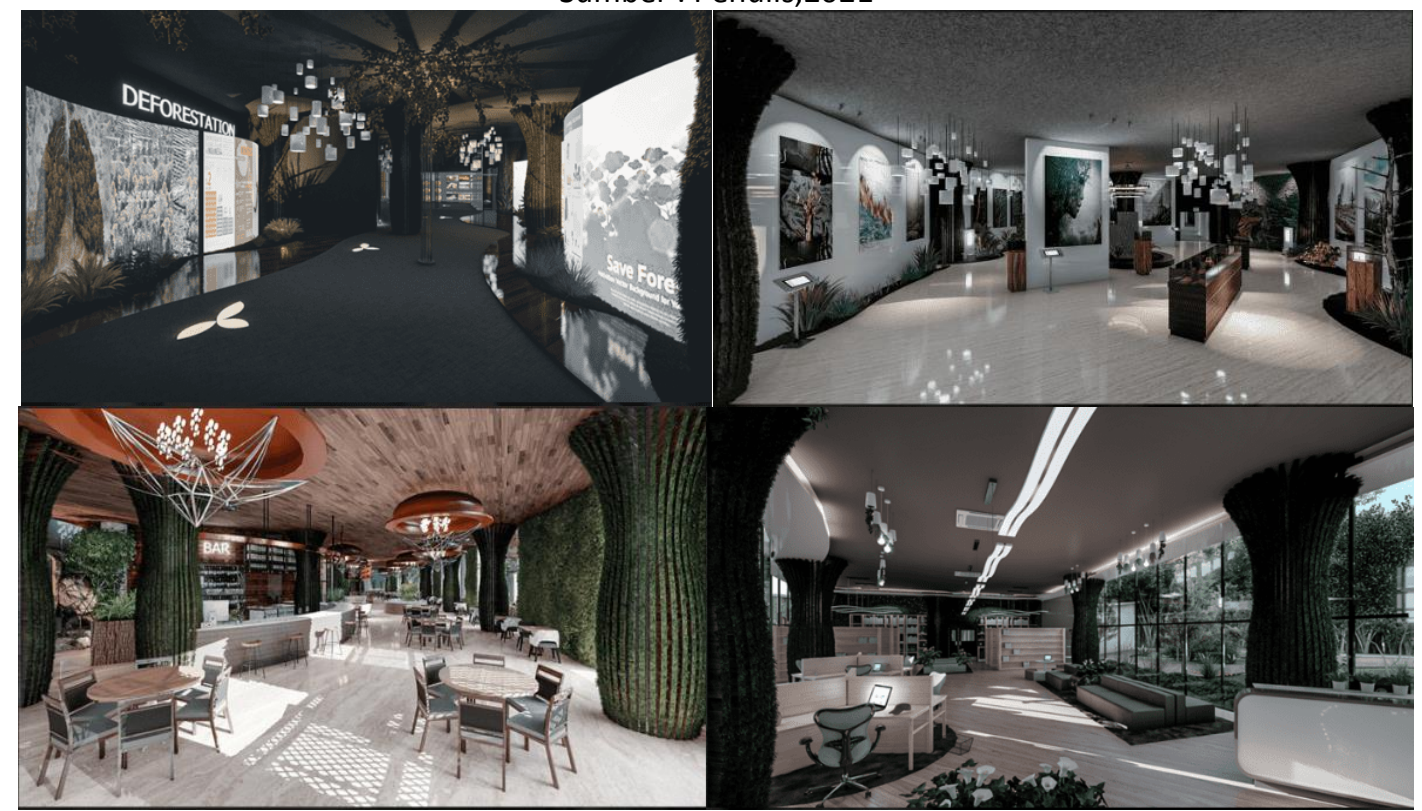

Gambar 20. Perspektif interior(Eksibisi,galeri,restaurant dan library) Sumber : Penulis,2021

\section{KESIMPULAN DAN SARAN}

\section{Kesimpulan}

Penerapan Biophilic design menghasilkan strategi perancangan menjadi sangat tepat dalam perancangan eduwisata hutan sehingga bisa merasakan seperti menyatu dengan alam. Teori ini lebih banyak menekankan pada bagaimana mengatur aspek-aspek fisik dari sebuah ruang sehingga dapat menciptakan lingkungan alam di dalam sebuah ruang. Penulis menghadirkan 
pengalaman ruang untuk pengguna disini mulai dari penentuan bukaan, pandangan langsung terhadap alam sesungguhnya, pengaturan ruang sehingga merasakan di alam dan bentuk yang dinamis untuk memperkuat kesan yang dialami dalam ruang maupun luar ruang sehingga menghasilkan fasilitas hiburan maupun edukasi untuk semua pengguna. Perancangan ini bertujuan untuk meningkatkan kesadaran bahayanya deforestasi serta memberikan informasiinformasi mengenai hutan dan deforestasi serta meningkatkan perkembangan wisata di Batam karena menjadi objek hiburan yang edukasi dan bermanfaat.

\section{Saran}

Saran untuk pengembangan studi dan desain yaitu sebagai berikut:

a. Penelitian perlu lebih banyak berkunjung ke eksbisi dan galeri mengenai hutan dan daerah hutan lainnya agar analisis dapat lebih optimal, dikarenakan adanya pandemic dan perijinan. Studi lapangan secara intensif diperlukan.

b. Studi ini masih dapat dikembangkan lagi dengan metode biophilic design dan perlu memilih material yang berasal dari alam

\section{REFERENSI}

Badan Pusat Statistik Kota Batam 2018. (2018). Kecamatan Nongsa dalam Angka.

Calabrese. E. F., Kellert. S. R. (2012). The Principles and Benefits of Biophilic Design. The Practice of Biophilic Design, 01, 6-19.

Damarraya, A., Ratnasari, M., \& Rhama, D. F. P. (2019). Deforestasi Indonesia Tahun 2017-2018. The Ecumenical Review, 64(2), 1-167.

Dinur. (2007). Ekology. Angewandte Chemie International Edition, 6(11), 951-952., 1-42.

Odum, E.P. 1996. Dasar-Dasar Ekologi. Edisi Ketiga. Yogyakarta: Gadjah Mada University Press

Frick H, Suskiyanto, B. (1998), Dasar-dasar Eko-arsitektur, Penerbit Kanisius, Yogyakarta.

Frick H, Mulyani, T.H. (2006), Arsitektur Ekologis, Penerbit Kanisius, Yogyakarta

Haq, A., \& Hornby, G. (n.d.). ECOTOURISM : A Strategy for Forest Conservation.

Kebudayaan, P. P., Tionghoa, T., \& Di, P. (2014). Bab III Tinjauan Kawasan/Wilayah Kota Batam Pusat Pengembangan Kebudayaan Tradisional Tionghoa Peranakan Di Batam.

Kellert, Stephen. R. (2008). Biophilic design. Chapter 1. Canada: John Wiley \& Sons Inc

Kellert, S and Calabrase, E. (2015). The Practice of Biophilic Design

M.P, A. I. R. (2018). Perencanaan Ekowisata Berbasis Sarana dan Prasarana.

Rautner, M., Leggett, M., \& Davis, F. (2013). Buku kecil pendorong besar deforestasi. 11-225.

Sekartjakrarini, S. (2009). Konsep Eco-tourism untuk Lanskap Trowulan.

Antaranews.com, "ha hutan lindung di Batam terbakar" https://www.antaranews.com/berita/797313/40-ha-hutan-lindung-di-batamterbakar diakses pada tanggal 7 april 2019, pukul 15.09 WIB.

Hazliansyah. (2014). 265 Hektare Hutan Lindung di Batam Terbakar. (Online). (http://www.republika.co.id/. diakses tanggal 30 Januari 2015)

Sekilas SDGs |. (n.d.). Retrieved July 3, 2021, from http://sdgs.bappenas.go.id/sekilas-sdgs/

Tewari, S. (2018). Landscape Urbanism. The Bloomsbury Encyclopedia of Design, April 2-4. https://doi.org/10.5040/9781472596161-bed-online-015

THE 17 GOALS | Sustainable Development. (n.d.). Retrieved July 3, 2021, from https://sdgs.un.org/goals

batamkota.bps.go.id, "luas hutan dan persentase hutan menurut fungsinya 2014", https://batamkota.bps.go.id/statictable/2015/12/17/34/luas-hutan-danpersentasehutan-menurut-fungsinya-2014.html, diakses pada 7 April 2019 pukul 14.35 WIB 